\title{
DISTRIBUTION AND STRUCTURE OF INTERNAL SECRETORY RESERVOIRS ON THE VEGETATIVE ORGANS OF INULA HELENIUM L. (ASTERACEAE)
}

\author{
Aneta Sulborska \\ Departament of Botany, Agricultural University of Lublin ul. Akademicka 15, 20950 Lublin \\ e mail: aneta.sulborska@ar.lublin.pl
}

Received: 16.04 .2007

\begin{abstract}
S u m m a r y
The aim of the study was to investigate the structure and topography of endogenous secretory tissues of Inula helenium L. By using light and electron microscopy, morphological and ana tomical observations of stems, leaves and rhizomes were made. It was shown that in the stems secretory cavities were situated in the vicinity of phloem and xylem bundles. The number of the reservoirs reached its maximum value (34) at shoot flowerig termination, whereas the cavities with the largest diameter were observed at full flowering stage $(44.6 \mu \mathrm{m})$. In the leaf petioles and midribs, the reservoirs also accompanied the vascular bun dles, and their number and size increased along with the growth of the assimilation organs. Observations of the cross sections of the rhizomes revealed the presence of several rings of secre tory reservoirs. The measurements of the cavities showed that as a rule the reservoirs with a larger dimension were located in the phelloderm, whereas the smallest ones in the xylem area. The secretory cavities located in the stems and leaves developed by schizogenesis, whereas the rhizome reservoirs were prob ably formed schizolisygenously. The cells lining the reservoirs formed a one four layered epithelium. Observed in TEM, the secretory cells of the mature cavities located in the rhizomes were characterised by the presence of a large central vacuole, whereas the protoplast was largely degraded. Fibrous elements of osmophilic secretion and numerous different coloured vesi cles could be distinguished in it. The cell walls formed, from the side of the reservoir lumen, ingrowths into the interior of the epithelial cells. Between the cell wall and the plasmalemma of the glandular cells, a brighter periplasmatic zone with secretory vesicles was observed.
\end{abstract}

Key words: secretory cavities, stem, leaf, rhizome, Inula helenium, Asteraceae

\section{INTRODUCTION}

Elecampane is an aromatic perennial originating from Central Asia, long run wild and cultivated in Europe, Asia Minor, Japan and North America. In Po- land it grows most frequently in thickets, forest fringes and near rivers, as well as it is grown in herb gardens (Strzelecka and Kowalski, 2000; LewkowiczMosiej, 2003; Szweykows cy, 2003).

Inula helenium, like many other plants from the Asteraceae family, has multiple applications in therapeutics. It is attributable to the presence of biologically active compounds contained in excretions of secretory tissues situated in different parts of plants.

The medicinal raw material of elecampane comprises its roots and rhizomes containing $1-3 \%$ of essential oil, polyacetylene compounds, a bitter substance alantopicrin, mineral salts and $44 \%$ of inulin (O ża row ski and Jaroniewski, 1987; Strzelecka and Kowalski, 2000; Lewkowicz-Mosiej, 2003). Extracts from roots and rhizomes are given in upper airway diseases and digestion disorders ( $\mathrm{O}$ żar ow ski and J a r oniewski, 1987; Lewkowicz-Mosiej, 2003). In China and Japan it is used in treatment of cholera and malaria, and externally it is applied as an antidote against snakes and venomous insects (Perry and Metzger, 1980).

It is known from reports of other authors that secretory ducts, running through the petiole to the leaf blade, occur in the stems of species from the genus Inula (Metcalfe and Chalk, 1957). In elecampane roots, $2 \mu \mathrm{m}$ long secretory cavities were observed (D e ry $\mathrm{ng}$, 1961). Bukowiecki and Furmanowa (1972) report that secretory cavities were found in rays, phloem and xylem of the underground organs.

However, we lack detailed information on the structure and topography of endogenous secretory tissues of Inula helenium. The aim of this study was to carry out an anatomical examination of the vegetative organs and the ultrastructure of cells, what may fill in the gap in this area. 


\section{MATERIAL AND METHODS}

The subject of the investigation was Inula heleni$u m$ L. (Asteraceae) plants from the tribe Inuleae (Wey mar, 1970; Heywood et al. 1977), coming from the Botanical Garden of the Maria Curie-Skłodowska University in Lublin. Anatomical observations were made in the years 1999-2003 from the start of vegetation of the investigated plants until its end.

In order to determine the type of secretory tissues and their location in the plants, stems, leaves and rhizomes were examined. Stem fragments $(2.5 \mathrm{~cm}$ long) were sampled from three places: at the base of the shoot, from the middle portion and from the portion under the inflorescence, taking into account different plant growth stages. The tissues of the leaf petioles and midribs, as well as the rhizome fragments were analysed. Initial observations were made on fresh material and fixed in $70 \%$ ethanol.

The number of secretory cavities was determined and their measurements were made $(n=30)$. In the cross sections, the size of the cavities was measured along their longer axis (together with the epithelium), as well as the length of the reservoir lumen (to simplify descriptions, the term "diameter length" is used in this paper). In the cross sections, the number of the epithelial cells, surrounding the cavity lumen, was also determined. In the case of the several-layered secretory tissue, the number of cells of the first layer of cells was given, counting from the lumen.

From fresh material and fixed in $70 \%$ ethanol, cross sections of the stems, leaf petioles, midribs and rhizomes, as well as longitudinal sections of the underground stems, were made manually. Sections embedded in glycerine were prepared, a part of which was stained with Sudan III and safranin. Observations and photos were made in a Eclipse 400, Nikon microscope.

Semithin sections $(0.5 \mu \mathrm{m}$ thick $)$ and ultrathin sections (60 nm thick) were also prepared. The stem and rhizome fragments were fixed in $2 \%$ paraformaldehyde with $2.5 \%$ glutaraldehyde in $0.1 \mathrm{M}$ cacodylate buffer with a pH of 7.4 at a temperature of $20^{\circ} \mathrm{C}$ for 2 hours, and then for 12 hours at a temperature of $4^{\circ} \mathrm{C}$. After the washing of the specimens for 24 hours in 0.1 $\mathrm{M}$ cacodylate buffer at a temperature of $4^{\circ} \mathrm{C}$ and postfixing them in $1 \% \mathrm{OsO}_{4}$, they were transferred to distilled water and stained in a $0.5 \%$ aqueous solution of uranyl acetate. At the next stage, the material was dehydrated in alcohol series and by using increasing concentrations of propylene oxide in alcohol, going over to pure propylene oxide. The specimens were embedded in Spurr Low Viscosity resin for 12 hours at a temperature of $70^{\circ} \mathrm{C}$. The semithin sections $(0.5 \mu \mathrm{m})$ were stained with $1 \%$ methylene blue with $1 \%$ azur II in a $1 \%$ aqueous solution of sodium tetraborate. Observations and photos were made by using a Jenaval Contrast and Eclipse 400,
Nikon microscope. To examine the cell ultrastructure, the material was cut into $60 \mathrm{~nm}$ thick sections by using the Reichert Ultracut S ultramicrotome. The ultrathin sections were treated with an $8 \%$ solution of uranyl acetate in $0.5 \%$ acetic acid and lead citrate. Observations and documentation were made by using the BS-500 Tesla electron microscope.

\section{RESULTS}

In the cross section, the above-ground stems of elecampane had a rounded and slightly flattened contour. Beneath the epidermis, several layers of collenchyma and cortex parenchyma were located (Fig. 1). The collateral bundles were surrounded by sclerenchyma fibres, making up expanded caps from the peripheral side of the stem (Figs. 1, 2 A). The interior of the stem was filled with a wide cylinder of pith parenchyma. The secretory cavities were located in the region of the phloem and xylem bundles at the level of the xylem, phloem or sclerenchyma caps (Figs. 1, 2 A). At the vegetative stage of shoot growth, the conducting bundles, accompanied by the cavities, were separated by $2-3$ vascular bundles by which no secretory reservoirs were observed. On the other hand, in the stems of the flowering plants each bundle was usually accompanied by the cavities, though there were also bundles by which no reservoirs occurred. In the region of a single vascular bundle, two cavities were most often located, one cavity on each side of the bundle (Figs. 1, 2 A), and sometimes only one secretory reservoir occurred. It also happened that four cavities accompanied a single phloem and xylem bundle, two on each side of the bundle. Apart from the main ring of the phloem and xylem bundles, additional smaller bundles were observed, located in the outer part of the stem, by which no cavities occurred. In the young shoots of elecampane, the reservoirs were poorly distinguished against the background of other cells, due to their small sizes (Fig. 3).

The shape of the secretory cavities in the stem cross section was close to rounded or oval (Figs. 2 B-7). The cavity lumen was surrounded by a single epithelium whose cells, along with the growth of the organ, split parallel to the cavity lumen forming 2-3 glandular layers. The cavities developed by schizogenesis, and their lumen enlarged by the gradual separation of the cells (Figs. 3, 5, 6). Thick cytoplasm was visible in the epithelial cells from the side of the reservoir lumen (Figs. $3,5)$. In the sections cut manually, the sclerenchyma tissue was observed surrounding the cavities or cells of the glandular layer with partly lignified walls (Fig. 4), what was confirmed by staining with safranin (Fig. 2 B). But in the $0.5 \mu \mathrm{m}$ thick sections, wall lignification was poorly visible, or it was not observed at all (Figs. 5, 6).

When analysing the different stem fragments, it was noted that the largest number of secretory cavities 

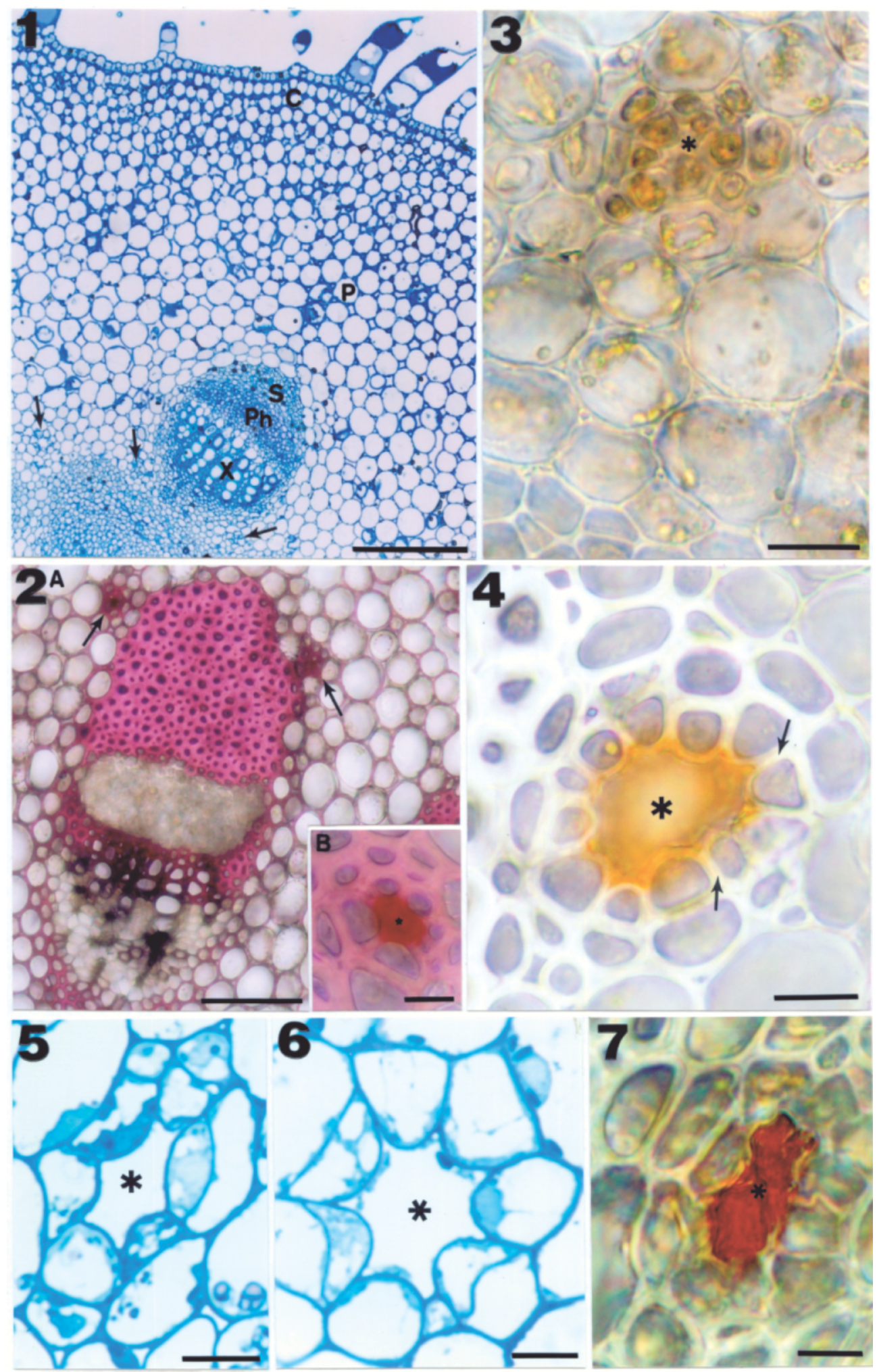

Fig. 1. Fragment of stem cross section with visible secretory cavities (arrows); c collenchyma, $p$ cortex parenchyma, s sclerenchyma, ph phloem, x xylem; (methylene blue with azur). Scale bar $200 \mu \mathrm{m}$.

Fig. 2 A. Location of secretory reservoirs (arrows) in stem cross section stained with safranin. Scale bar $100 \mu \mathrm{m} .2 \mathrm{~B}$. Close up of the secretory reservoir (asterisk); (safranin). Scale bar $10 \mu \mathrm{m}$.

Fig. 3. Secretory reservoir (asterisk) in stem cross section at vegetative stage; (Sudan III). Scale bar $20 \mu \mathrm{m}$.

Figs. 4 7. Cross sections of secretory cavities (asterisks) in stems of flowering plants. In Fig. 4 lignified walls of glandular cells visible (arrows); (Figs. 4, 7 no staining; Figs. 56 methylene blue with azur). Scale bar $10 \mu \mathrm{m}$. 
Table 1

Some parameters characterizing of the secretory reservoirs in a stem.

\begin{tabular}{|c|c|c|c|c|c|}
\hline \multirow{2}{*}{$\begin{array}{l}\text { Development stage } \\
\text { of plant }\end{array}$} & \multirow[t]{2}{*}{ Fragment of stem } & $\begin{array}{l}\text { Number of } \\
\text { reservoirs }\end{array}$ & $\begin{array}{c}\text { Diameter of } \\
\text { reservoirs }(\mu \mathrm{m})\end{array}$ & $\begin{array}{l}\text { Diameter } \\
\text { of reservoir } \\
\text { lumen }(\mu \mathrm{m})\end{array}$ & $\begin{array}{c}\text { Number of } \\
\text { secretory cells }\end{array}$ \\
\hline & & $\begin{array}{l}\text { range } \\
\text { mean }\end{array}$ & $\begin{array}{l}\text { range } \\
\text { mean }\end{array}$ & $\begin{array}{l}\text { range } \\
\text { mean }\end{array}$ & $\begin{array}{l}\text { range } \\
\text { mean }\end{array}$ \\
\hline \multirow{3}{*}{ Vegaetative stage } & $\begin{array}{c}02 \mathrm{~cm} \text { above the root } \\
\text { neck }\end{array}$ & $\begin{array}{c}2528 \\
\mathbf{2 6 . 3}\end{array}$ & $\begin{array}{c}24.473 .3 \\
\mathbf{3 7 . 6} \\
\end{array}$ & $\begin{array}{c}8.140 .7 \\
\mathbf{1 7 . 8} \\
\end{array}$ & $\begin{array}{c}5.013 .0 \\
7.4 \\
\end{array}$ \\
\hline & $\begin{array}{c}1 / 2 \text { of the length of } \\
\text { the stem }\end{array}$ & $\begin{array}{l}15 \\
15\end{array}$ & $\begin{array}{c}18.036 .0 \\
\mathbf{2 6 . 5}\end{array}$ & $\begin{array}{c}5.120 .7 \\
\mathbf{1 1 . 7}\end{array}$ & $\begin{array}{c}5.07 .0 \\
\mathbf{5 . 8}\end{array}$ \\
\hline & $\begin{array}{l}02 \mathrm{~cm} \text { below the } \\
\text { shoot apex }\end{array}$ & $\begin{array}{l}20 \\
\mathbf{2 0}\end{array}$ & $\begin{array}{c}12.838 .5 \\
\mathbf{2 5 . 3} \\
\end{array}$ & $\begin{array}{c}2.625 .7 \\
\mathbf{1 0 . 9} \\
\end{array}$ & $\begin{array}{c}4.08 .0 \\
\mathbf{5 . 7} \\
\end{array}$ \\
\hline \multirow{3}{*}{ Full flowering } & $\begin{array}{c}02 \mathrm{~cm} \text { above the root } \\
\text { neck }\end{array}$ & $\begin{array}{l}28 \\
\mathbf{2 8}\end{array}$ & $\begin{array}{c}20.672 .4 \\
\mathbf{4 0 . 4} \\
\end{array}$ & $\begin{array}{c}7.746 .3 \\
\mathbf{2 0} \\
\end{array}$ & $\begin{array}{c}6.012 .0 \\
7.3 \\
\end{array}$ \\
\hline & $\begin{array}{c}1 / 2 \text { of the length of } \\
\text { the stem }\end{array}$ & $\begin{array}{l}23 \\
23\end{array}$ & $\begin{array}{c}27.748 .9 \\
\mathbf{3 7}\end{array}$ & $\begin{array}{c}14.727 .7 \\
\mathbf{1 9}\end{array}$ & $\begin{array}{c}6.016 .0 \\
\mathbf{9 . 3}\end{array}$ \\
\hline & $\begin{array}{c}02 \mathrm{~cm} \text { below the } \\
\text { shoot apex }\end{array}$ & $\begin{array}{l}31 \\
\mathbf{3 1}\end{array}$ & $\begin{array}{c}36.082 .2 \\
\mathbf{5 6 . 3} \\
\end{array}$ & $\begin{array}{c}12.843 .7 \\
\mathbf{2 8} \\
\end{array}$ & $\begin{array}{c}6.014 .0 \\
8.8 \\
\end{array}$ \\
\hline \multirow{3}{*}{$\begin{array}{l}\text { Flowering } \\
\text { termination }\end{array}$} & $\begin{array}{c}02 \mathrm{~cm} \text { above the root } \\
\text { neck }\end{array}$ & $\begin{array}{l}30 \\
\mathbf{3 0}\end{array}$ & $\begin{array}{c}16.363 .1 \\
\mathbf{3 8 . 1} \\
\end{array}$ & $\begin{array}{c}5.239 .0 \\
\mathbf{1 9 . 3} \\
\end{array}$ & $\begin{array}{c}5.010 .0 \\
7.2 \\
\end{array}$ \\
\hline & $\begin{array}{l}1 / 2 \text { of the length of } \\
\text { the stem }\end{array}$ & $\begin{array}{l}34 \\
34\end{array}$ & $\begin{array}{c}15.464 .2 \\
\mathbf{3 7 . 8}\end{array}$ & $\begin{array}{c}5.138 .5 \\
\mathbf{1 7 . 5}\end{array}$ & $\begin{array}{c}5.010 .0 \\
7\end{array}$ \\
\hline & $\begin{array}{l}02 \mathrm{~cm} \text { below the } \\
\text { shoot apex }\end{array}$ & $\begin{array}{c}39.41 \\
\mathbf{3 9 . 3} \\
\end{array}$ & $\begin{array}{c}18.048 .8 \\
\mathbf{3 2} \\
\end{array}$ & $\begin{array}{c}5.138 .5 \\
\mathbf{1 2 . 4} \\
\end{array}$ & $\begin{array}{c}5.010 .0 \\
\mathbf{6 . 9} \\
\end{array}$ \\
\hline
\end{tabular}

Table 2

Some features of the secretory reservoirs in a leaf.

\begin{tabular}{|c|c|c|c|c|c|}
\hline \multirow[t]{2}{*}{ Part of leaf } & \multirow{2}{*}{ Age of leaf } & $\begin{array}{l}\text { Number of } \\
\text { secretory } \\
\text { reservoirs }\end{array}$ & $\begin{array}{c}\text { Diameter } \\
\text { of secretory } \\
\text { reservoir }(\mu \mathrm{m})\end{array}$ & $\begin{array}{l}\text { Diameter } \\
\text { of reservoir } \\
\text { lumen }(\mu \mathrm{m})\end{array}$ & $\begin{array}{c}\text { Number of } \\
\text { secretory cells }\end{array}$ \\
\hline & & $\begin{array}{l}\text { range } \\
\text { mean }\end{array}$ & $\begin{array}{l}\text { range } \\
\text { mean }\end{array}$ & $\begin{array}{l}\text { range } \\
\text { mean }\end{array}$ & $\begin{array}{l}\text { range } \\
\text { mean }\end{array}$ \\
\hline \multirow{2}{*}{ Petiole } & Jung & $\begin{array}{l}2 \\
2\end{array}$ & $\begin{array}{c}33.438 .5 \\
\mathbf{3 5 . 3}\end{array}$ & $\begin{array}{c}18.025 .7 \\
\mathbf{2 1 . 2}\end{array}$ & $\begin{array}{c}5.06 .0 \\
5.5\end{array}$ \\
\hline & Mature & $\begin{array}{c}9.027 .0 \\
\mathbf{1 8 . 7}\end{array}$ & $\begin{array}{c}25.784 .8 \\
\mathbf{5 0 . 1}\end{array}$ & $\begin{array}{c}12.864 .2 \\
\mathbf{2 9 . 6}\end{array}$ & $\begin{array}{c}4.09 .0 \\
\mathbf{5 . 7}\end{array}$ \\
\hline \multirow[b]{2}{*}{ Midrib } & Jung & \multicolumn{4}{|c|}{ Reservoirs were no observed } \\
\hline & Mature & $\begin{array}{c}7.013 .0 \\
\mathbf{1 0 . 2}\end{array}$ & $\begin{array}{c}29.660 .4 \\
\mathbf{4 3 . 9}\end{array}$ & $\begin{array}{c}7.737 .3 \\
\mathbf{2 0 . 4}\end{array}$ & $\begin{array}{c}4.08 .0 \\
6\end{array}$ \\
\hline
\end{tabular}




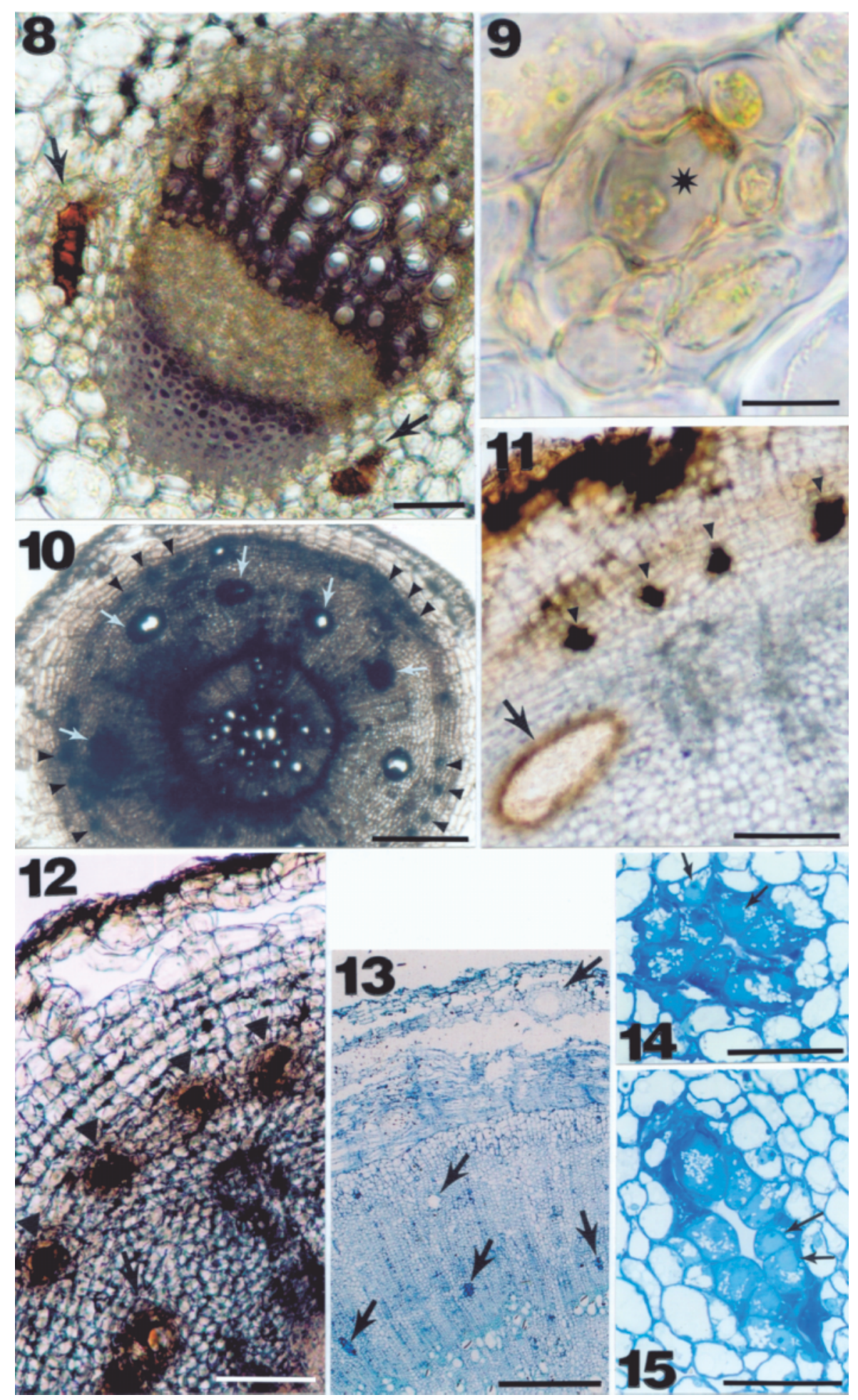

Fig. 8. Location of secretory cavities (arrows) in leaf petiole cross section; (no staining). Scale bar $50 \mu \mathrm{m}$.

Fig. 9. Cross section of secretory reservoir in leaf petiole. Secretion (asterisk) visible in the reservoir lumen; (no staining). Scale bar $10 \mu \mathrm{m}$.

Figs. 10 12. Secretory cavities in rhizome cross sections. Clusters of first forming cavities (arrow heads) and reservoirs of the next ring (arrows) are visible.; (Fig. $10 \mathrm{OsO}_{4}$; Figs. 1112 no staining). Fig. 10 scale bar $500 \mu \mathrm{m}$, figs. 1112 scale bar $200 \mu \mathrm{m}$.

Fig. 13. Fragment of rhizome cross section with secretory cavities at different growth stages (arrows); (methylene blue with azur). Scale bar $500 \mu \mathrm{m}$.

Figs. 14 15. Secretory cavities at secretion stage located in deeper layers of rhizome (arrows). Large cell nuclei visible in epithelial cells (arrows); (methylene blue with azur). Scale bar $50 \mu \mathrm{m}$. 


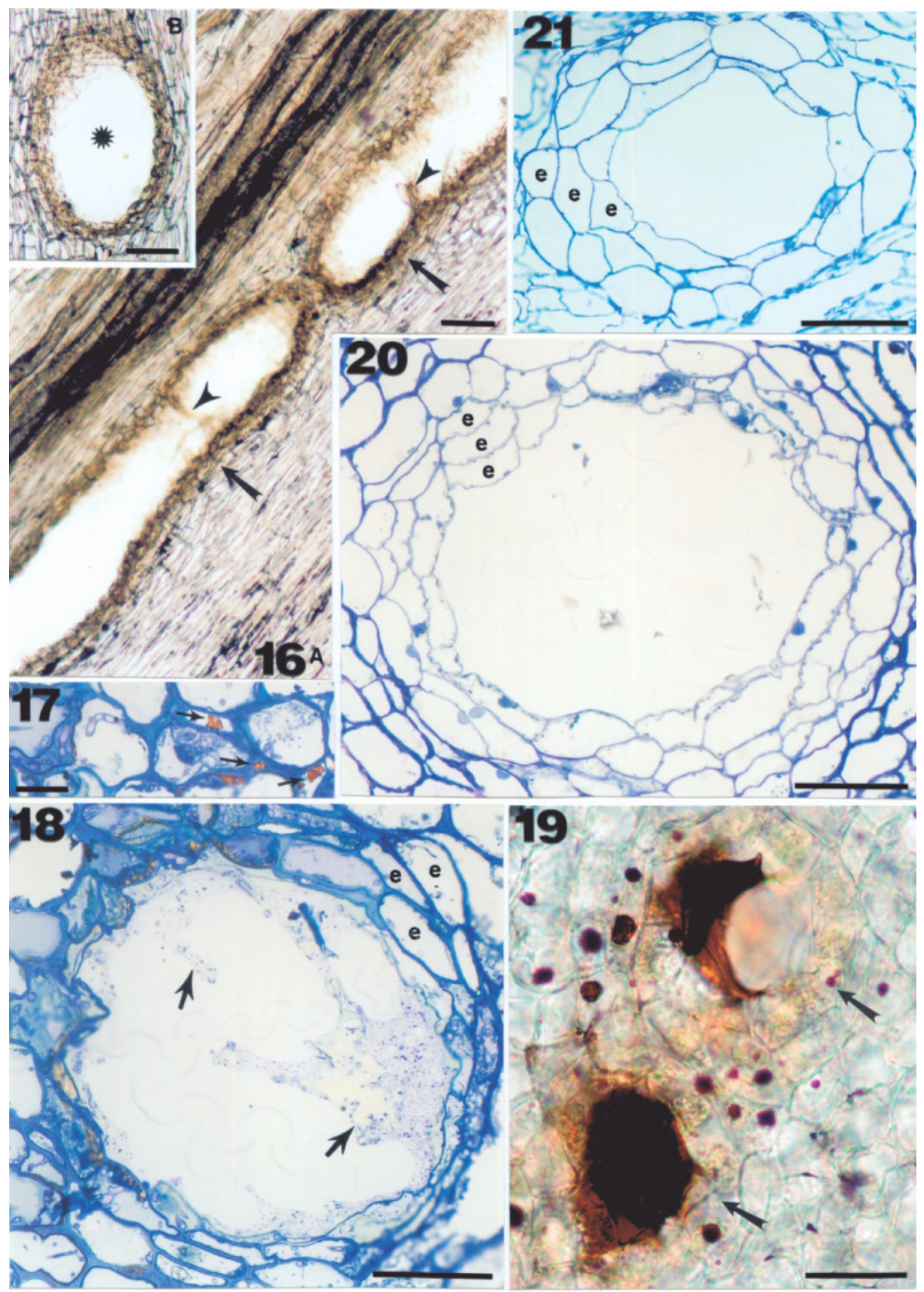

Figs. 16 A. Ellipsoidal secretory cavities (arrows) arranged in rows in rhizome tissues in longitudinal section. In the cavity lumen remnants of cell walls which underwent lysis (arrow heads) are visible, indicating the fusion of cavities. 16 B. Secretory cavity (asterisk) in longitudinal section; (no staining). Scale bar $100 \mu \mathrm{m}$.

Fig. 17. Crystallised secretion (arrows) in cells and intercellular spaces surrounding the secretory cavity; (methylene blue with azur). Scale bar $20 \mu \mathrm{m}$.

Fig. 18. Reservoir from the phelloderm of rhizome. Flattened cells of epithelium (e) containing orange secretion are visible. In the reservoir lumen secretory substance is contained (arrows); (methylene blue with azur). Scale bar $50 \mu \mathrm{m}$.

Fig. 19. Secretory cavities (arrows) in rhizome cross section with dark content; (no staining). Scale bar $50 \mu \mathrm{m}$.

Fig. 20. Mature secretory cavity in rhizome lined with several layered epithelium (e); (methylene blue with azur). Scale bar $50 \mu \mathrm{m}$.

Fig. 21. Secretory reservoir from the phelloderm of rhizome at post secretion stage surrounded by epithelial cells (e); (methylene blue with azur). Scale bar $50 \mu \mathrm{m}$. 

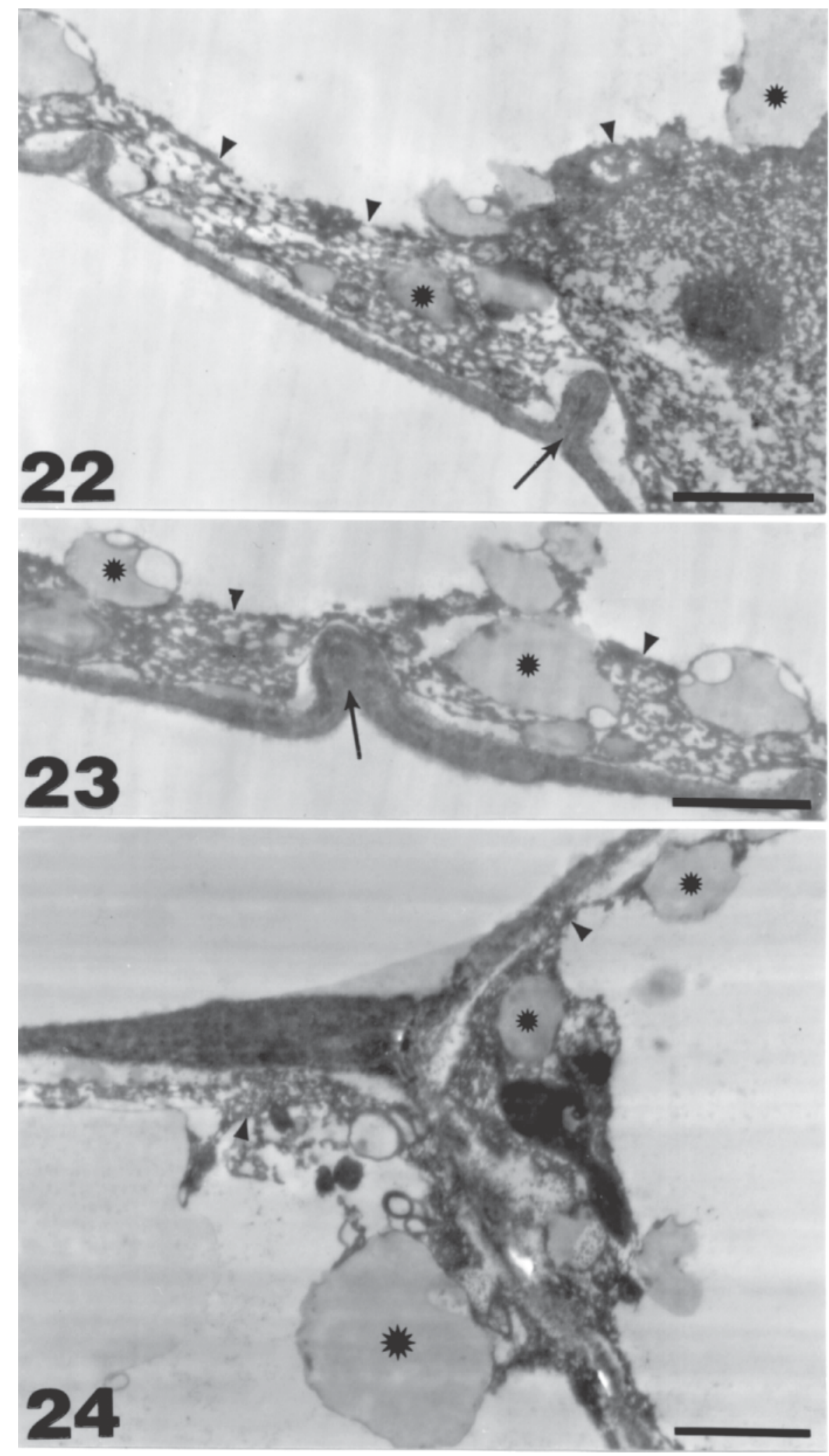

Figs. 22 24. Fragments of cells of the first epithelium layer of cavities located in rhizome. In peripheral cytoplasm, vesicles with secretion (asterisks), fibrous structures (arrow heads) and cell wall ingrowths (arrows) are visible. Scale bar $2 \mu \mathrm{m}$. 

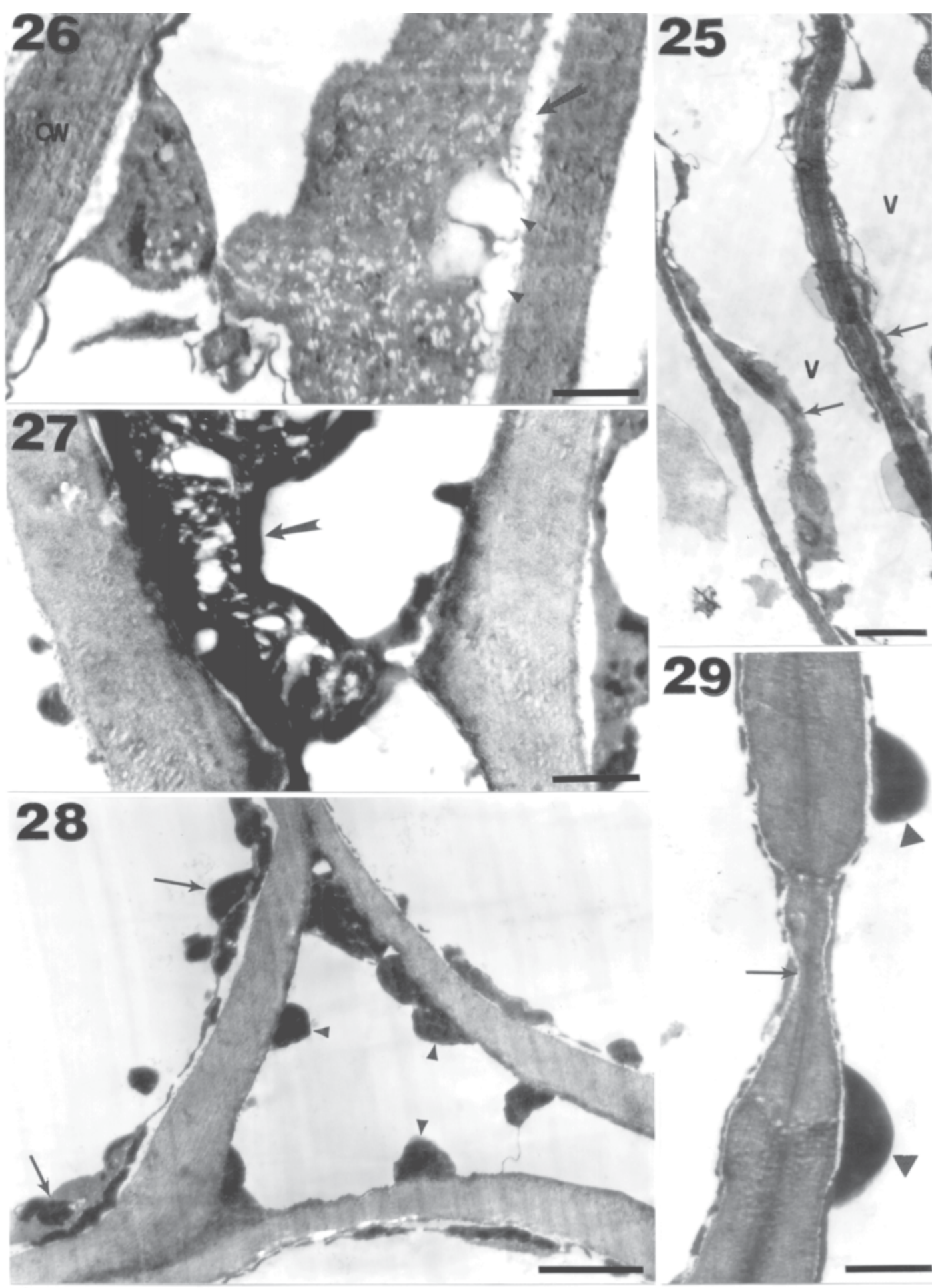

Fig. 25. Fragments of glandular cells with a large central vacuole (v) and degraded protoplast with remnants of secretory material (arrows). Scale bar $2 \mu \mathrm{m}$.

Fig. 26. Fragment of a glandular cell with thick walls (cw) surrounding the cavity in rhizome. In bright periplasmatic space (arrow) secretory vesicles (arrow heads) are present. Scale bar $1 \mu \mathrm{m}$.

Fig. 27. Intercellular space in epithelium lining the cavity in rhizome. Arrow indicates heterogeneous secretion. Scale bar $1 \mu \mathrm{m}$.

Fig. 28. Fragments of parenchymal cells surrounding secretory cavities in rhizome. Secretion is visible inside cells (arrows) and in intercellular spaces (arrow heads). Scale bar $2 \mu \mathrm{m}$.

Fig. 29. Fragment of the parenchymal cell wall located around the cavity in rhizome with visible pits (arrow) and peripherally located secretion (arrow heads). Scale bar $1 \mu \mathrm{m}$. 
formed as a rule in the upper sections of the aboveground shoots, and the amount of reservoirs was the largest at shoot flowering termination. In particular stages of the vegetation period, the diameter of the cavities reached $29.8-44.6 \mu \mathrm{m}$, on average, with its maximum values at full flowering stage. A comparison of the long axis of the reservoir lumen showed the occurrence of the smallest and largest values, respectively, in the reservoirs from the stems at the vegetative stage $(13.5 \mu \mathrm{m})$ and at full flowering stage $(22.3 \mu \mathrm{m})$. An analysis of the epithelium revealed that the number of glandular cells, depending on the place of location in the stem and the growth stage, was 4-16 (Tab. 1).

In the leaf petioles and midribs, the secretory cavities were observed in the vicinity of the primary and smaller vascular bundles in the cross sections of these organs. The secretory reservoirs were located by the side of the vascular bundles at the level of the sclerenchyma caps, phloem and xylem, or at the border of the sclerenchyma and phloem (Fig. 8). The shape of the cavities was close to rounded or oval. The epithelium lining the reservoirs was composed of 1-2 layers of cells (Fig. 9). A comparison of the petioles and midribs in the young and mature leaves revealed an increase in the number of cavities in the mature organs. The diameter of the cavities also increased. The reservoirs were characterised by the epithelium composed of 5.5-6 cells, on the average (Tab. 2).

In the rhizomes of elecampane, several rings of secretory cavities formed, the number of which increased along with the growth of the organ. In the cross sections of the young underground stems, the cavities of the outer ring were marked by a very dark content and small dimensions compared to the cavities formed later. They were arranged in characteristic arches in the secondary cortex parenchyma, composed of 3-5 cavities each (Figs. 10-12). During the growth of the rhizome in thickness, new reservoirs formed in the cortex and in the xylem area, reaching different dimensions (Figs. 10-13; Tab. 3). Larger cavities were often observed deeper inside the rhizome (secondary xylem), and smaller ones in the outer rings, what can evidence the formation of the cavities "de novo". At the successive growth stages of the underground stems, the outer tissues peeled off, together with the cavities (Fig. 13). The round or oval, in the cross section, secretory reservoirs were lined with, depending on the growth stage, a one-four-layered epithelium. In the $0.5 \mu \mathrm{m}$ thick sections, very thick cytoplasm, intensively stained under the influence of toluidine blue, was visible inside the young glandular cells; thereby these cells were easily distinguished from the adjacent tissues. In addition, large nuclei and numerous, fine vacuoles were present in them (Figs. 14, 15). The epithelium surrounding the older cavities was characterised by flattened cells, tightly packed around the cavity lumen, and their protoplast was gradually degraded (Figs. 18-21). In the cavity lumen, there was variously stained liquid secretion (Figs. 18, 19). In the glandular cells and intercellular spaces, a crystallised orange secretory substance was also observed (Figs. 17, 18). The parenchymal cells surrounding the cavities were characterised by thickened walls (Figs. 18, 20). They probably formed an envelope protecting the cavities against crushing.

Table 3

A comparison of the size of the secretory reservoirs located in the different regions of a rhizome.

\begin{tabular}{|c|c|c|c|c|c|c|}
\hline \multirow{3}{*}{$\begin{array}{l}\text { Diameter of } \\
\text { rhizome }(\mathrm{mm})\end{array}$} & \multicolumn{3}{|c|}{ Diameter of secretory reservoirs $(\mu \mathrm{m})$} & \multicolumn{3}{|c|}{ Diameter of reservoir lumen $(\mu \mathrm{m})$} \\
\hline & in phelloderm & $\begin{array}{c}\text { in cortex } \\
\text { parenchyma }\end{array}$ & in xylem & in phelloderm & $\begin{array}{c}\text { in cortex } \\
\text { parenchyma }\end{array}$ & in xylem \\
\hline & $\begin{array}{l}\text { range } \\
\text { mean }\end{array}$ & $\begin{array}{l}\text { range } \\
\text { mean }\end{array}$ & $\begin{array}{l}\text { range } \\
\text { mean }\end{array}$ & $\begin{array}{l}\text { range } \\
\text { mean }\end{array}$ & $\begin{array}{l}\text { range } \\
\text { mean }\end{array}$ & $\begin{array}{l}\text { range } \\
\text { mean }\end{array}$ \\
\hline \multicolumn{7}{|c|}{ Cross sections } \\
\hline 2 & $\begin{array}{c}33.4133 .6 \\
\mathbf{6 8 . 8}\end{array}$ & $\begin{array}{c}48.8154 .2 \\
\mathbf{6 4 . 2}\end{array}$ & $\begin{array}{c}28.3102 .8 \\
\mathbf{5 0 . 9}\end{array}$ & $\begin{array}{c}15.487 .4 \\
\mathbf{3 9}\end{array}$ & $\begin{array}{c}15.43 .1 \\
\mathbf{6 4 . 2}\end{array}$ & $\begin{array}{c}12.872 .0 \\
\mathbf{2 8 . 5}\end{array}$ \\
\hline 4.5 & $\begin{array}{c}48.8128 .5 \\
77\end{array}$ & $\begin{array}{c}128.5287 .8 \\
\mathbf{1 8 5 . 9}\end{array}$ & $\begin{array}{c}30.854 .2 \\
\mathbf{1 0 0 . 9}\end{array}$ & $\begin{array}{c}30.892 .5 \\
\mathbf{5 4 . 3}\end{array}$ & $\begin{array}{c}64.2205 .6 \\
\mathbf{1 2 2 . 5}\end{array}$ & $\begin{array}{c}25.7115 .6 \\
\mathbf{5 6 . 3}\end{array}$ \\
\hline 20 & $\begin{array}{c}218.4578 .2 \\
\mathbf{3 5 0 . 8}\end{array}$ & $\begin{array}{c}231.3488 .3 \\
\mathbf{3 1 4 . 1}\end{array}$ & $\begin{array}{c}48.8346 .9 \\
\mathbf{1 4 4}\end{array}$ & $\begin{array}{c}128.5346 .9 \\
\mathbf{2 3 2 . 6}\end{array}$ & $\begin{array}{c}136.2346 .9 \\
\mathbf{2 2 9 . 8}\end{array}$ & $\begin{array}{c}12.8218 .4 \\
\mathbf{9 4 . 9}\end{array}$ \\
\hline \multicolumn{7}{|c|}{ Longitudinal sections } \\
\hline 9 & & $\begin{array}{c}244.15796 .7 \\
\mathbf{3 1 4 . 8}\end{array}$ & $\begin{array}{c}141.351233 .6 \\
\mathbf{3 9 7 . 4}\end{array}$ & & $\begin{array}{c}105.4308 .4 \\
\mathbf{2 3 8 . 4}\end{array}$ & $\begin{array}{c}51.41156 .5 \\
\mathbf{3 0 0 . 8}\end{array}$ \\
\hline
\end{tabular}


The longitudinal sections of the elecampane underground stem revealed the occurrence of rows of ovalshaped cavities, separated by parenchymal cells (Figs. 16 A, B). Sometimes, the cavities were situated close to each other, as well as they merged together, what is evidenced by the remnants of cell walls visible in the reservoir lumen (Fig. $16 \mathrm{~A}$ ). The fusion of the cavities may indicate the fact that the cavities in the rhizomes formed schizolisygenously.

A comparison of the underground stems showed that in the organs with a diameter of $2 \mathrm{~mm}$ and $20 \mathrm{~mm}$ the largest secretory reservoirs occurred in the outer ring. In the $4.5 \mathrm{~mm}$ thick rhizomes, the cavities reaching the maximum values were located slightly deeper in the cortex (tab. 3). The measurements of the diameter of the cavity lumen show that in most cases the cavities with the largest clearance were situated in the cortex and had the size of 64.3-229.8 $\mu \mathrm{m}$. On the other hand, the smallest reservoir lumen had cavities located in the xylem area (Tab. 3).

In the epithelial cells of the mature secretory cavities, the cytoplasm was limited to the peripheral region, and the cell interior was filled with a large central vacuole (Fig. 25). The cell protoplast was largely degraded, fibrous elements and numerous vesicles with different degrees of osmophilicity, accumulating mainly along the cell wall and in the vacuole, could be distinguished in it (Figs. 22-24). The cell walls were electron dense, forming from the side of the cavity lumen characteristic ingrowths into the interior of the epithelial cells, thereby their active surface increased (Figs. 22, 23). Between the cell wall and the plasmalemma of the glandular cells, a brighter periplasmatic zone was observed in which secretory vesicles were visible (Fig. 26). The secretion accumulated not only in the reservoir lumen, but also in the spaces between the epithelial cells (Fig. 27).

In the parenchymal cells surrounding the cavities, as well as in the intercellular spaces of the parenchyma, droplets of dark secretion were visible, what indicated the interaction of these two tissues (Fig. 28). The thick walls of the parenchyma cells had characteristic narrowings with the location of pit fields in which plasmodesmata ran (Fig. 29).

\section{DISCUSSION}

Literature data show that internal secretory structures in the form of ducts and cavities are widespread in the Asteraceae family (Metcalfe and Chalk, 1957; Lersten and Curtis, 1988).

Numerous publications discuss endogenous secretory tissues in different Asteraceae plants, however, information on the structure and arrangement of these structures in Inula helenium is fragmentary.

As a result of the studies conducted it can be stated that the secretory reservoirs in the stems, leaf petioles and midribs of elecampane were located in the vicinity of the vascular bundles, and in the rhizomes in the secondary cortex and the xylem area. These observations are partially consistent with literature data which show that the secretory cavities in this species occurred in underground organs in the area of xylem, phloem and parenchyma rays (B ukowiecki and Furmanowa, 1972). Other authors give the location of the reservoirs in the stems in the cortex area or in the region of the endodermis (Metcalfe and Chalk, 1957; Deryng 1961). In many Asteraceae representatives, the reservoirs were also located in the stem in the region of the endodermis, in the receptacle (Kołdowski et al. 1955; Metcalfe and Chalk, 1957; Weryszko-Chmielewska etal. 1999), as well as in leaf petioles and midribs in the vicinity of vascular bundles (Łotocka and Geszprych, 2004), or were dispersed in the area of externally located tissues (Maksymowy ch and Ledbetter, 1987).

In the presented study it was noted that the stem and leaf secretory cavities were often situated in the vicinity of the phloem. Such a location of the reservoirs may be an effective protection against piercing and sucking insects. Such a correlation is evidenced by the occurrence of secretory reservoirs already in young leaves, thus in the most sensitive organs during the early plant growth stages. Probably, the cavities may also conduct or contain substances toxic to insects and other herbivores (Maksymowych and Ledbetter, 1987). Gommers (1981) reports that thiophenes and polyacetylenes present in Tagetes patula roots show strong nematocidal activity of plants, like substances secreted by Artemisia trifida roots (Gommers, 1981; Wang et al. 1998).

Observations made in this study show that the size and number of cavities in the above-ground organs of elecampane were dependent on the plant growth stage and the location of the reservoirs in the stem. The diameter of the stem cavities measured in the cross sections along the long axis ranged 12.9-82.2 $\mu \mathrm{m}$. In the underground shoots, there were cavities with a diameter of 28.3-578.3 $\mu \mathrm{m}$ in the cross section and with a length of 141.4-1233.6 $\mu \mathrm{m}$ in the longitudinal section. The reservoirs situated in the leaf petioles and midribs, depending on the growth stage, reached 25.7-84.8 $\mu \mathrm{m}$ and 0-60.4 $\mu \mathrm{m}$, respectively. These results are partially consistent with reports of authors investigating other Asteraceae species, who give $80-100 \mu \mathrm{m}$ for the cavities of Tagetes patula (Poli et al. 1995) and a length of $15-25 \mu \mathrm{m}$ and a width of 12-15 $\mu \mathrm{m}$ for the cavities of Eupatorium rugosum (Lersten and Curtis 1986). In literature, there is little information on the size of the secretory reservoirs in Inula helenium. Only Deryng (1961) reports that the length of the cavities in its roots may reach up to $2 \mathrm{~mm}$.

The reservoirs located in the stems and leaves of the species investigated in the study developed as a result of the separation of a group of cells which enlarged the reservoir lumen existing between them. It leads to a conclusion that these structures are of schizogenous origin. 
In the case of the cavities situated in the rhizomes, the schizolisygenous formation of the reservoirs probably occurs. In the longitudinal sections, the remnants of cell walls which underwent lysis, remaining after the fusion of the adjacent cavities, were visible inside the cavity lumen. The resin ducts of Parthenium argentatum, which were initiated schizogenously, but their further development was schizolisygenous, formed in a similar way ( $\mathrm{J}_{\mathrm{O}-}$ seph et al. 1988). However, the schizogenous formation of secretory reservoirs is most frequently encountered in Asteraceae representatives (Botha and Herman, 1980; Maksymowych and Ledbetter, 1987; Lersten and Curtis, 1987; Torres and Robles, 1996; Luque, 2001, Sacchetti et al. 2001; Łotocka and Geszprych, 2004). The lisygenous (Anderson and Creech, 1975; Monteiro et al. 1999) and pseudoschizogenous (Curtis and Lersten, 1986) formation of glandular structures was also observed, but it was not observed in the taxon investigated in the study.

The secretory cavities of elecampane, depending on the place of occurrence, were surrounded by 14 layers of glandular cells. In other representatives of this family, a uniseriate epithelium occurred (Lersten and Curt is , 1987; P oli et al. 1995), biseriate (Ler s te $n$ and Curtis 1987, 1988; Poli et al. 1995), one-twolayered (Torres and Roblem, 1996), multi-layered (Monteiro et al. 1999; Simonet et al. 2002) or composed of two cells (Curtis and Lersten, 1986). The glandular cells lining the cavities in the stems and leaves of the species investigated in the study were characterised by lignified walls. F a h n (2000) reports that the outer layer of the secretory complex cells can have thick walls and form a protective sheath, whereas the inner layer of the epithelium is the most active in the secretion process. The epithelium with lignified cell walls was also observed in Cnicus benedictus (Metcalfe and Chalk, 1957).

Observations made using transmission electron microscopy revealed that the cell walls of the epithelium lining the rhizome cavities of elecampane were electron dense and thick. In the direction of the protoplast interior, they formed ingrowths and folds which evidenced the transfer character of these cells. As reported by $\mathrm{He}$ jnowicz (2002), the conducting (transfer) cells occur where an intensive transport takes place between cells through the walls separating them. In the walls of the epithelial cells of elecampane, no plasmodesmata were observed, however, pit fields were visible in the walls of the parenchymal cells surrounding the reservoirs, indicating the presence of cytoplasmic strands joining the adjacent protoplasts, thereby indicating the cooperation of the epithelium with the subepithelial tissues. The interaction of both tissues is also indicated by the presence of droplets of secretion inside the parenchyma cells and in the spaces between the parenchyma cells. In the periplasmatic space and in the close vicinity of the walls of the glandular cells, numerous vesicles were observed containing a heterogeneous secretory substance. Similar structures in the form of vesicles were also described in other Asteraceae representatives (Sacchetti et al. 2001). The presence of the vesicles was probably associated with the granulocrine mechanism of release of secretory material. The secretory substances in the species investigated in the study also accumulated in the intercellular spaces and inside the vacuoles. The accumulation of secretion in the vacuoles was probably transitional. Maksymowych and Ledbetter (1987) suggested that droplets of the heterogeneous substance separated from the tonoplast by vesiculation, passed through the cytoplasm, and then were fused with the plasmalemma. At a later stage, the secretion accumulated in the periplasmatic space, from where it was conveyed to the reservoir lumen.

\section{CONCLUSIONS}

1. In the stems and leaves of elecampane, a single ring of secretory cavities was observed in the region of the vascular bundles, whereas in the rhizomes several rings of secretory cavities occurred and they were located in the phelloderm, cortex parenchyma and the xylem area

2 . The secretory reservoirs of the largest and the smallest diameter were observed in the rhizomes and in the stems, respectively.

3 . The epithelium of the biggest thickness characterized the reservoirs located in the rhizomes, whereas the cavities in the leaves were marked by the smallest thickness.

4. The secretory reservoirs located in the stems and leaves were formed schizogenously, whereas the cavities in the rhizomes had a schizolisygenous origin.

\section{REFERENCES}

Anderson L. C., Creech J.B. 1975. Comparative leaf anat omy of Solidago and related Asteraceae. Amer. J. Bot. 62 (5): 486493.

Botha C. E. J., Herman P.P. J. 1980. Some observations on the anatomy of Artemisia afra Jacq. Jl S. Afr. Bot. 46 (2): 197206.

Bukowiecki H., Furmanowa M. 1972. Botanika farma ceutyczna. PZWL, Warszawa: 443450.

Curtis J.D., Lersten N.R. 1986. Development of bicellular foliar secretory cavities in white snakeroot, Eupatorium rugosum (Asteraceae). Amer. J. Bot. 73 (1): 7986.

Deryng J. 1961. Atlas sproszkowanych roślinnych surowców leczniczych. PZWL, Warszawa.

Fahn A. 1988. Secretory tissues and factors influencing their development. Phyton, 28 (1): 1326.

Fahn A. 2000. Structure and function of secretory cells. Adv. Bot. Res. 31: 3775 .

Gommers F. J. 1981. Biochemical interactions between nema todes and plants and their relevance to control. Helminth Abs. Ser. B, Plant Nematol. 50: 924. 
Guttenberg H. 1968. Der primäre Bau der Angiospermenwu rzel. In: Handbuch der Pflanzenanatomie. Bd. VIII, T1.5. Gebrüder Borntraeger, Berlin Nikolassee.

Hejnowicz Z. 2002. Anatomia i histogeneza roślin naczynio wych. Wydawnictwo Naukowe PWN, Warszawa.

Heywood V. H., Harborne J. B., Turner B.L. 1977. The biology and chemistry of the Compositae. Vol. I, Acade mic Press, London, New York, San Francisco.

Hillson C.J. 1979. Leaf development in Senecio rowleyanus (Compositae). Amer. J. Bot. 66 (1): 5963.

Joseph J. P., Shah J. J., Inamdar J.A. 1988. Distribu tion, development and structure of resin ducts in guayule (Parthenium argentatum Gray). Ann. Bot. 61: 377387.

Kołdowski M., Wysocka Rumińska A., Tałałaj S., Wiszniewski J. 1955. Rośliny olejkowe i olejki natu ralne. PWRiL, Warszawa.

Lersten N. R., Curtis J. D. 1986. Tubular cavities in white snakeroot, Eupatorium rugosum (Asteraceae). Amer. J. Bot. 73 (7): 10161021.

Lersten N. R., Curtis J.D. 1987. Internal secretory spaces in Asteraceae. A review and original observations on Conyza canadensis (tribe Astereae). La Cellule, 74: 181196.

Lersten N.R., Curtis J. D. 1988. Secretory reservoirs (ducts) of two kinds in giant ragweed (Ambrosia trifida; Astera ceae). Amer. J. Bot. 75 (9): 13131323.

Lewkowicz Mosiej T. 2003. Leksykon roślin leczniczych. Świat Książki, Warszawa.

Luque R. 2001. Cavidades secretoras en la raiz de Espeletiinae (Asteraceae). Plantula, 3 (1): 19

Łotocka B., Geszprych A. 2004. Anatomy of the vegetative organs and secretory structures of Rhaponticum carthamoides (Asteraceae). Bot. J. Linn. Soc. 144: 207233.

Maksymowych R., Ledbetter M.C. 1987. Fine structure of epithelial canal cells in petioles of Xanthium pensylvanicum. Amer. J. Bot. 74 (1): 6573.

Metcalfe C. R., Chalk L. 1957. Anatomy of the Dicotyle dons. V. II. Oxford at the Clarendon Press: 782804.

Monteiro W. R., Fahn A., Caldeira W., Castro M. 1999. Ultrastructural observations on the foliar secretory cavities of Porophyllum lanceolatum DC. (Asteraceae). Flora, 194: 113126.

Ożarowski A., Jaroniewski W. 1987. Rośliny lecznicze i ich praktyczne zastosowanie. Instytut Wydawniczy Związków Zawodowych, Warszawa.

Perry L. M., Metzger J. 1980. Medicinal plants of east and southeast Asia. The MIT Press Cambrige, Massachusetts and London, England.

Poli F., Sacchetti G., Bruni A. 1995. Distribution of in ternal secretory structures in Tagetes patula (Asteraceae). Nord. J. Bot. 15 (2): 197205.

Torres F., Robles L. 1996. Anatomia foliar de las especies de Paragynoxys Cuatrec. (Asteraceae) del Estado Mérida, Venezuela. Plantula, 1 (2): 151165.

Sacchetti G., Romagnoli C., Bruni A., Poli F. 2001. Secretory tissue ultrastructure in Tagetes patula L. (Asteraceae) and thiophene localization through $\mathrm{X}$ ray mi croanalysis. Phyton 41 (1): 3548 .
Simon P. M., Katinas L., Arambarri M. 2002. Secretory tissues in Tagetes minuta (Asteraceae, Helenieae). Bole tin SAB, 37 (1 2): 181191.

Strzelecka H., Kowalski J. (red.), 2000. Encyklopedia zielarstwa i ziołolecznictwa. Wydawnictwo Naukowe PWN, Warszawa.

Szweykowska A., Szweykowski J. 2003. Słownik bota niczny. Wiedza Powszechna, Warszawa.

Wang W., Zhu X.R., Liu W.Z. 1988. Influence of ragweed (Ambrosia trifida) on plant parasitic nematodes. J. Chem. Ecol. 24: 17071714.

Weryszko Chmielewska E., Kowalski T., Wolski T. 1999. Rożnik przerośnięty (Silphium perfoliatum L.) nowa roślina alternatywna. I. Cechy morfologiczne i ana tomiczne. Zesz. Prob. Nauk Rol. 468: 495503.

Weymar H. 1970. Buch der Korbblütler. Neuman Verlag, Le ipzig.

\section{Rozmieszczenie i struktura wewnętrznych zbiorników wydzielniczych w organach wegetatywnych Inula helenium L. (Asteraceae)}

\section{Streszczenie}

Celem pracy było zbadanie struktury i topografii endogennych tkanek wydzielniczych Inula helenium L. Wykorzystując mikroskopię świetlną i elektronowa przeprowadzano obserwacje morfologiczno-anatomiczne łodyg, liści i kłączy. Wykazano, że w łodygach zbiorniki wydzielnicze usytuowane były w sąsiedztwie wiązek łyko-drzewnych. Liczebność rezerwuarów osiagała maksimum (34) w fazie przekwitania pędów, zaś zbiorniki o największej średnicy obserwowano podczas pełni kwitnienia (44,6 $\mu \mathrm{m})$. W ogonkach i nerwach głównych liści rezerwuary towarzyszyły również wiązkom przewodzącym a ich liczba i średnica wzrastała wraz z rozwojem organów asymilacyjnych. Obserwacje przekrojów poprzecznych kłączy ujawniły obecność kilku pierścieni rezerwuarów wydzielniczych. Pomiary zbiorników pokazały, że z reguły rezerwuary o największej średnicy zlokalizowane były w felodermie, najmniejsze zaś na obszarze ksylemu. Zbiorniki wydzielnicze usytuowane $\mathrm{w}$ łodygach i liściach powstawały na drodze schizogenezy, rezerwuary kłączowe zaś prawdopodobnie formowały się schizolizygenicznie. Komórki wyścielające rezerwuary tworzyły 1-4-warstwowy epitel. Oglądane w TEM komórki wydzielnicze dojrzałych zbiorników zlokalizowanych w kłączach, cechowały się obecnością dużej centralnej wakuoli, protoplast zaś był w znacznym stopniu zdegradowany. Można było wyróżnić w nim fibrylarne elementy osmofilnej wydzieliny oraz liczne, różnobarwne pęcherzyki. Sciany komórkowe tworzyły od strony luki ekskretów wpuklenia do wnętrza komórek epitelialnych. Pomiędzy ścianą komórkową a plazmolemą komórek gruczołowych obserwowano jaśniejszą strefę peryplazmatyczną z pęcherzykami wydzielniczymi. 